\title{
Synthesis and Characterization of Al-doped NiO Nanostructured Thin Films Elaborated by Solar Spray Pyrolysis Technique, for Photovoltaic Cells
}

\author{
Abdelbaki Nid a,b, *, Lilia Zighed c , Yacine Aoun ${ }^{\text {d,e }}$, Bedreddine Maaoui d,e \\ ${ }^{a}$ Mechanical Department, Faculty of Technology, University of Skikda, Skikda 21000, Algeria \\ ${ }^{b}$ LGMM Laboratory, Faculty of Technology, University of Skikda, Skikda 21000, Algeria \\ ${ }^{c}$ LGCES Laboratory, Faculty of Technology, University of Skikda, Skikda 21000, Algeria \\ ${ }^{d}$ Mechanical Department, Faculty of Technology, University of El-Oued, El-Oued 39000, Algeria \\ ${ }^{e}$ VTRS Laboratory, Faculty of Technology, University of El-Oued, El-Oued 39000, Algeria \\ *e-mail:ab.nid@univ-skikda.dz
}

\begin{abstract}
In this experimental work, pure nickel oxide and Al-doped $\mathrm{NiO}$ thin films have successfully been elaborated onto glass substrates by solar spray pyrolysis technique. The substrates were heated at around $450^{\circ} \mathrm{C}$ using a solar heater (furnace). The structural, optical and electrical properties of the elaborated Al-doped films have been studied at different atomic percentage ratios $(0,0.5,1,1.5$ and 2 at. \%). The results of Al-doped $\mathrm{NiO}$ films XRD patterns were, the formation of $(\mathrm{NiO})$ phase under a cubic crystalline structure (polycrystalline) with a strong favored orientation along (111) plane were noticed at all sprayed films. When $\mathrm{Al}$ doping ratio reaches 1 at.\%, an growth in crystallite size over $31.9 \mathrm{~nm}$ was obtained denoting the nano-structure of the product, which confirmed by SEM images. In addition, aluminum oxide $\mathrm{Al}_{2} \mathrm{O}_{3}$ was clearly observed at 1.5 at.\% $\mathrm{Al}$ ratio. Otherwise, all thin films have a good optical transmission in the visible region of about $65 \%$, the optical band gap energy decreased from 3.69 to $3.64 \mathrm{eV}$ with increasing $\mathrm{Al}$ doping ratio. It is shown that the layer deposited with 0.5 at.\% has less disorder with few defects. The investigation on electrical properties of elaborated thin films confirmed that the conductivity of $\mathrm{NiO}$ films was improved, after doping them with $\mathrm{Al}$ which affirms their p-type character of semiconductor. However, an addition of an excessive quantity of $\mathrm{Al}$ content causes the formation of $\mathrm{Al}_{2} \mathrm{O}_{3}$ which leads to a decrease in the conductivity. It is worth mentioning that the $\mathrm{Al}$ content of 0.5 at.\% is the optimum ratio in terms of electrical conductivity and formation defect. Al-doped $\mathrm{NiO}$ can be used in various optoelectronic devices due to its good transparency and high electrical conductivity.
\end{abstract}

Keywords: Nickel oxide; Thin films; Al doping ratio; Solar spray pyrolysis; Solar heater; Furnace.

\section{INTRODUCTION}

The recent research report that, the semiconductors as metallic oxides are essential compounds for the development of gas sensors, lithium ion micro-batteries, cathode materials for alkaline batteries, optoelectronics and ultrahigh frequencies components [1-2]. Among these, Nickel oxide (NiO) is a transparent p-type semiconducting material (TCO) has a direct large gap, and wide range of applications, such as gas sensors, UV photo-detector, dye-sensitized solar cells, electro-chromic coatings and counter electrodes layers of solid oxide fuel cells (SOFC) [3-4]. It has potential applications for solar cells is owing to its p-type character, gas sensors is due to its wide band gap (3.6-4.0eV), defrosting windows, transparent diodes and transistors because their transparency, it can be also used for 
touch screens and UV photo-detectors because of their good responsively [5-6].

Nanostructure $\mathrm{NiO}$ thin films can be elaborated by several techniques such as sputtering, electron beam evaporation, molecular beam epitaxy, chemical vapor deposition, electrodeposition, spray pyrolysis and sol-gel process [7-8]. Among these processes, we will concentrate more particularly in this search on the spray pyrolysis, due to its various benefits such as inexpensive apparatus, wide homogeneous area, and easy control of the deposited films structure [9-10].

The aim of this search is to obtain Al-doped $\mathrm{NiO}$ thin films for optoelectronic applications, with a different heating way through using a solar heater (furnace) to economize the electrical energy and protect user from chemicals by working outside laboratories. The solar furnace (parabolic dish) consisted of a mirror layer inside (ITO glass) with parabolic reflector and a substrate holder at its focal point. It uses solar energy to heat a glass substrate fixed on the holder by reflecting the incident rays on it. The thin films can be deposited by spray pyrolysis (pneumatic) technique onto $450^{\circ} \mathrm{C}$ heated glass substrates with various doping ratios of $0.5,1$, 1.5 and 2 at. \%. Investigation and characterization of structural and optical properties, of prepared thin films, were

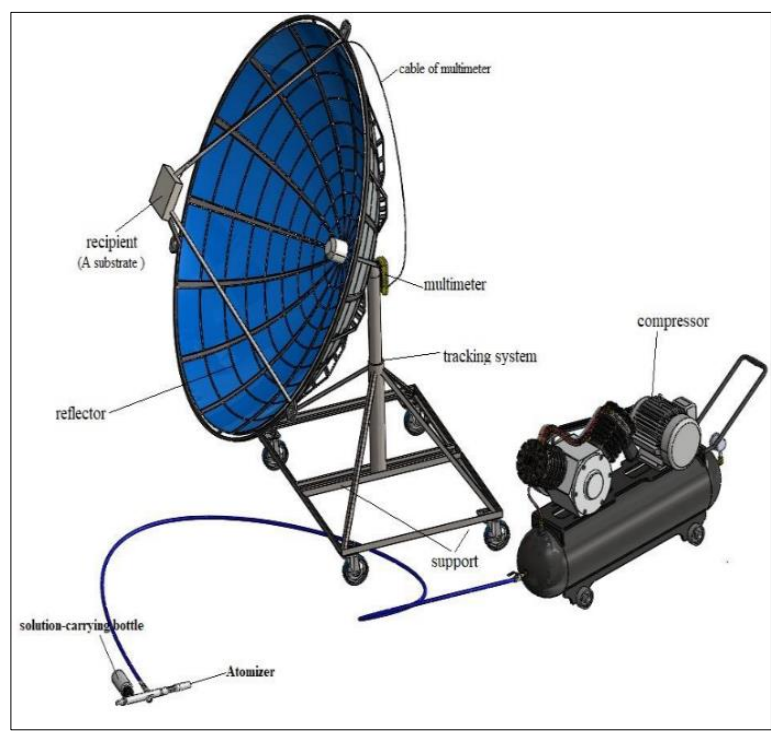

Figure 1. (a) Complete assembly of the experimental setup (Designed by SolidWorks) performed using X-ray diffraction, scanning electron microscope (SEM) and UV-visible spectroscopy. While for electrical properties, four-point probe were processed on all samples to correlate them to $\mathrm{Al}$ doping ratio.

\section{EXPERIMENTS}

Nickel (II) nitrate hexahydrate (Ni $\left.\left(\mathrm{NO}_{3}\right)_{2} \cdot 6 \mathrm{H}_{2} \mathrm{O}\right)$ was used to prepare $\mathrm{NiO}$ solution $(0.1 \mathrm{M})$, and $\mathrm{AlCl}_{3} \cdot \mathrm{H}_{2} \mathrm{O}$ for $\mathrm{Al}_{2} \mathrm{O}_{3}$ solution. The solutions are mixed in volume equal volume of water. The Al contents are $0,0.5,1,1.5$ and 2 at.\%, the mixture solution was stirred for $3 \mathrm{~h}$ at RT and heated at $50^{\circ} \mathrm{C}$ to yield a clear solution, in this setup drops of $\mathrm{HCl}$ can be added as a stabilizer with heating. After that, various $\mathrm{Al}$ doping ratios of $\mathrm{NiO}$ thin films were sprayed on $450^{\circ} \mathrm{C}$ preheated glass substrates by solar spray pneumatic method using solar furnace (see Figure $1 \mathrm{a}$ and $1 \mathrm{~b}$ ) for 5 minutes of deposition time. The obtained Al-doped $\mathrm{NiO}$ thin films have been characterized to identify the crystal structure, optical transmission and electrical conductivity by X-ray diffraction with an X-ray diffractometer (Bruker-AXS type $8 \mathrm{D}$, with $\lambda=$ $0.15406 \mathrm{~nm}$ and 20: 20-80 ), Phenom ProX scanning electron microscope (SEM) an UVvisible spectrophotometer (Lambda 35 with wavelength range of 300-900 nm) and four-point method was performed by Keithley Model 2400LV SourceMeter instrument, respectively.

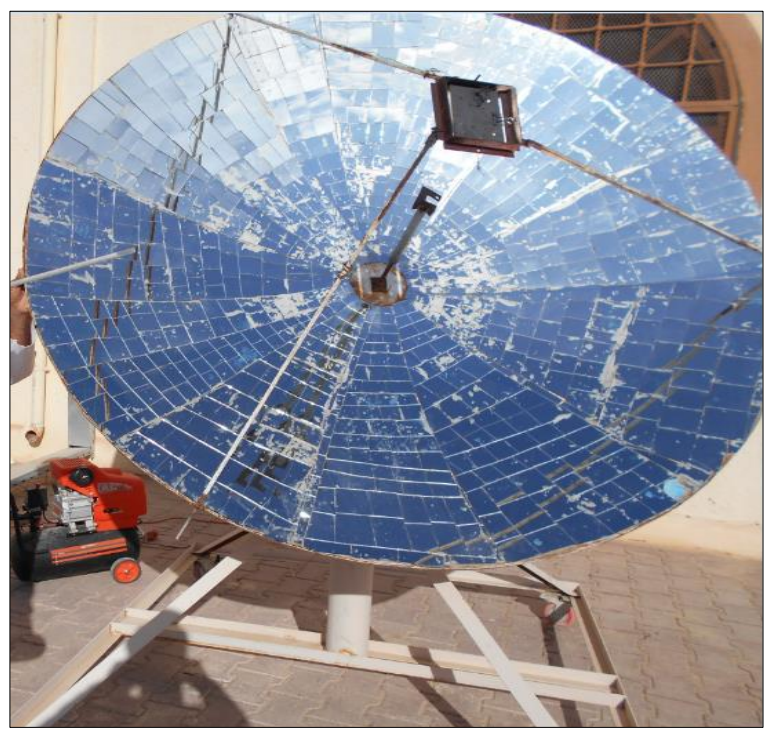

(b) A picture of the used solar furnace 


\section{RESULTS AND DISCUSSION}

\section{Structural Properties of Al-doped NiO Thin Films}

The effects of $\mathrm{Al}$ doping on crystal structure and favored orientations were studied by characterizing all sprayed Al-doped $\mathrm{NiO}$ thin films using the XRD technique. Figure 2 shows the XRD patterns of obtained thin films deposited with several $\mathrm{Al}$ doping ratios of $0,0.5,1,1.5$ and 2 at.\%. As a first result, All films showed three diffraction peaks at $2 \theta=37,43$ and $79^{\circ}$ related to (111), (200) and (222) planes of $\mathrm{NiO}$ phase, denoting that NiO:Al thin films are polycrystalline (cubic structure), which is in a good accord with JCPDS data (card number 471049) [11]. The produced crystalline structures have strong peaks, corresponded to (111) crystal plane of the $\mathrm{NiO}$ face centered cubic (fcc) structure. It can be seen that the intensities of the (111) diffraction peaks of sprayed Al-doped $\mathrm{NiO}$ thin films compared to pure $\mathrm{NiO}$ film have good crystallinities, which affirmed the improvement of crystalline quality and reducing of crystal structure defects. The inset graph in Figure 2 shows the variations of diffraction angle and FWHM of the (111) diffraction. The smaller diffraction angle of the position peak was obtained for 1.5 at.\%, indicating the increase in the interplanar spacing $d_{111}$ (see Table1). However, the maximum value of the FWHM of the (111) peak measured for pure NiO film. The second result, it was observed at $2 \theta=29.3^{\circ}$ in the diffraction peak corresponding to appearance of a second phase getting clear at 0.15 at.\% related to $\mathrm{Al}_{2} \mathrm{O}_{3}$ due to the abundance of $\mathrm{O}^{-2}$ outdoors, unlike inside laboratories.

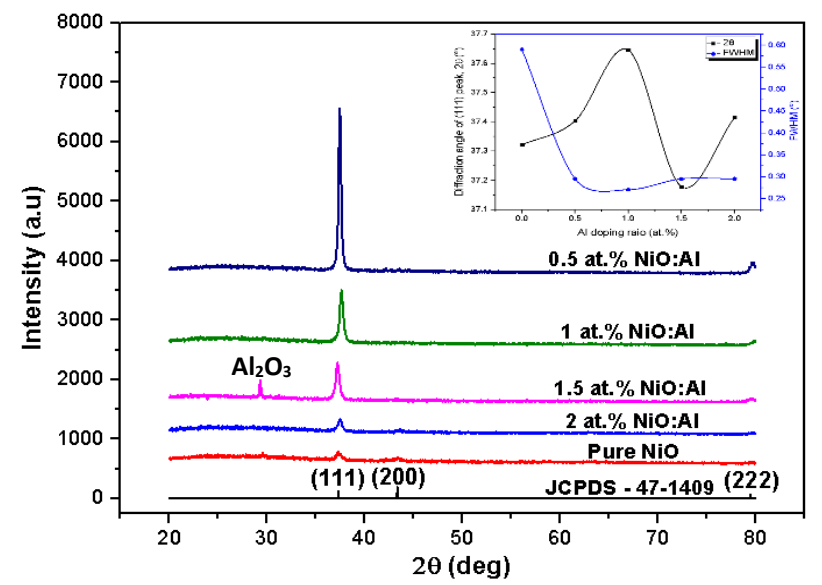

Figure 2: X-Ray diffraction spectra of NiO:Al thin films elaborated at $450^{\circ} \mathrm{C}$ with various $\mathrm{Al}$ doping ratio (at.\%). The inset graph shows diffraction angle and FWHM variations of the (111) peak.
In order to get further structural information, several structural parameters of Al-doped $\mathrm{NiO}$ thin films elaborated with various $\mathrm{Al}$ doping ratio were calculated, such as interplanar spacing $d_{\mathrm{hkl}}$, lattice constant $a$, grain size $G$, lattice strain $\varepsilon$, and dislocation density $\delta$.

In the cubic structure case, the lattice constant $a$ was calculated using the following formula (1) [12]:

$$
\frac{1}{d_{h k l}^{2}}=\frac{h^{2}+k^{2}+l^{2}}{a^{2}}
$$

Where $h k l$ are Miller indices, and $d_{\mathrm{hkl}}$ is the interplanar spacing calculated by Bragg's law [13]:

$$
2 d_{h k l} \sin \theta=n \lambda
$$

Where $\theta$ is the Bragg diffraction angle of peak in degree, $n$ is the order of diffraction taken equal unity (first order), and $\lambda$ is the wavelength of the incident radiation $(\lambda=1.5406 \AA)$.

The crystallite size $G$ of the films was calculated for (111) plane using Scherrer's formula [14-15]:

$$
G=\frac{0.9 \lambda}{\beta \cos \theta}
$$

Where $\lambda$ is the $\mathrm{X}$-ray wavelength and $\beta$ is the full width at half maximum (FWHM) corresponding to Bragg's diffraction angle $\theta$.

The dislocation density $\delta$, which is defined as the dislocation lines per unit volume of crystal, was calculated using the following formula [16]:

$$
\delta=\frac{1}{G^{2}}
$$

Table 1 sums up the structural parameters variations of elaborated $\mathrm{Al}$-doped $\mathrm{NiO}$ thin films with various $\mathrm{Al}$ doping ratios. Crystallite size $G$ and lattice strain $\varepsilon$ variations along the (111) plane as a function of $\mathrm{Al}$ doping ratio are plotted in Figure 3.

It can be seen, the crystallite size increased to reach its maximum value of $31.9 \mathrm{~nm}$ at 1 at.\% of $\mathrm{Al}$, which maybe owing to the improvement of the crystalline quality. Whereas $\mathrm{Al}$ ratio exceeded 1 at.\%, its size slightly decreased and fixed at $29.2 \mathrm{~nm}$. At 1 at.\%, the strain had a low value due to decreasing of lattice parameter [17].

The prepared film with $\mathrm{Al}$ content of 1 at.\% presents the high value of crystallite size (31.9 $\mathrm{nm})$ revealing the nanostructure of film. The increase in the crystallite size denotes a reducing in lattice defects, which in turn reduces dislocation density and strain (densely packed structure) [17] as shown in Table 1. 
Table 1: Structural parameters deduced from the (111) peak of Al-doped NiO thin films with various Al doping ratios

\begin{tabular}{|c|c|c|c|c|c|c|c|}
\hline $\begin{array}{c}\text { Al doping } \\
\text { ratio } \\
\text { (at. \%) }\end{array}$ & $\begin{array}{c}\text { Diffraction } \\
\text { angle } 2 \theta \\
\left({ }^{\circ}\right)\end{array}$ & $\begin{array}{c}\text { FWHM } \\
\beta\left(^{\circ}\right)\end{array}$ & $\begin{array}{l}\text { interplanar } \\
\text { spacing } d_{h k l} \\
\text { (§) }\end{array}$ & $\begin{array}{l}\text { Crystallite } \\
\text { size } G \\
(\mathbf{n m})\end{array}$ & $\begin{array}{c}\text { Lattice } \\
\text { parameter } \\
a(\mathbf{n m})\end{array}$ & $\begin{array}{c}\text { Lattice } \\
\text { strain } \varepsilon \\
(\%)\end{array}$ & $\begin{array}{c}\text { Dislocation } \\
\text { density } \sigma \\
\left(\text { lines } / \mathrm{m}^{2}\right)\end{array}$ \\
\hline 0 & 37.322 & 0.590 & 2.409 & 14.4 & 0.417 & 0.762 & 4.823 \\
\hline 0.5 & 37.404 & 0.295 & 2.404 & 29.2 & 0.416 & 0.380 & 1.173 \\
\hline 1 & 37.646 & 0.271 & 2.389 & 31.9 & 0.414 & 0.347 & 0.983 \\
\hline 1.5 & 37.179 & 0.295 & 2.418 & 29.2 & 0.419 & 0.383 & 1.173 \\
\hline 2 & 37.415 & 0.295 & 2.404 & 29.2 & 0.416 & 0.380 & 1.173 \\
\hline
\end{tabular}

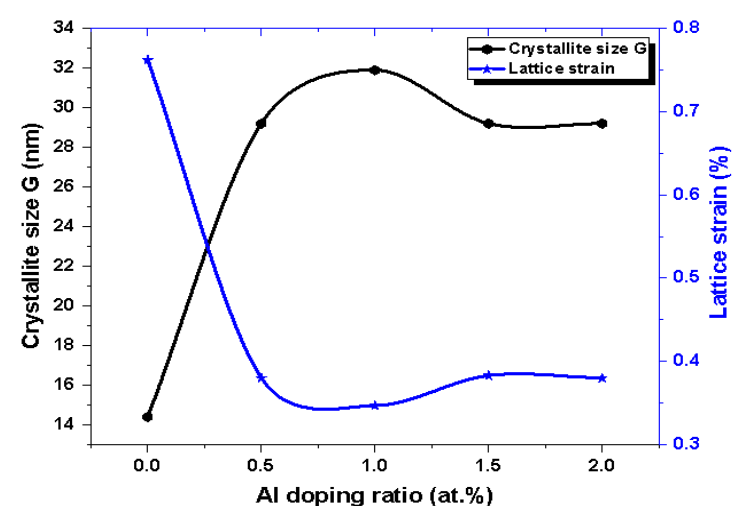

Figure 3: Crystallite size and lattice strain variations of $\mathrm{NiO}: \mathrm{Al}$ thin films as a function of Al doping ratio.

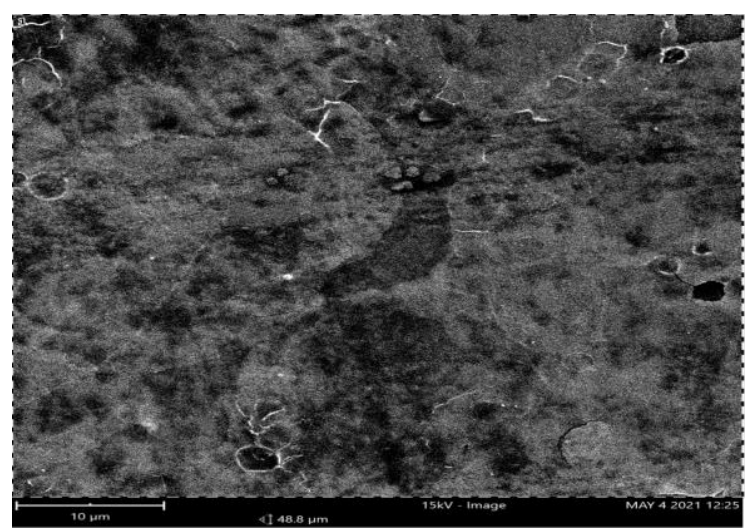

(a)

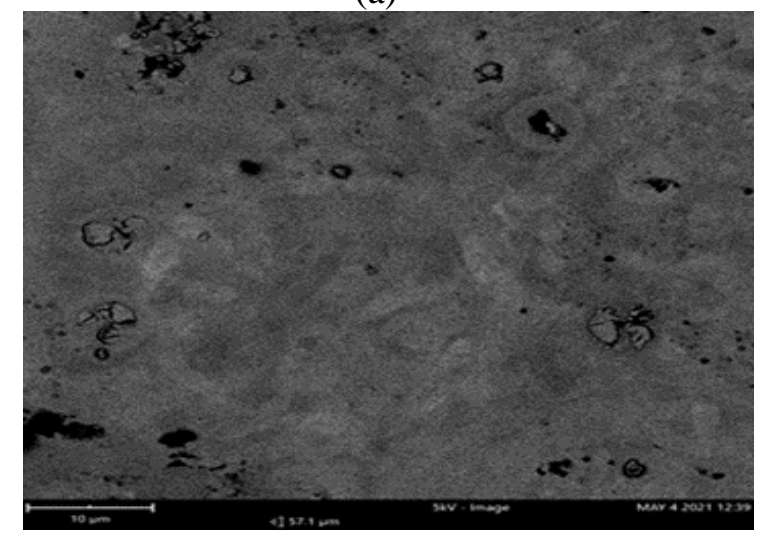

(c)
Figures 4(a)-4(d) represent the SEM images of surface morphologies of the samples with different $\mathrm{Al}$ atomic percentage ratios $(0.5,1$, 1.5 and 2 at. \%). As can be seen, with increasing $\mathrm{Al}$ atomic percentage ratio to 1.5 at.\%, the substrate becomes well covered with presence of nanoagglomerations along the surface of the substrate as seen in Figure 3(c). Beyond 1.5 at.\% as $\mathrm{Al}$ atomic percentage, the substrate becomes completely covered with $\mathrm{NiO}$ and films exhibing that nanoagglomerations continue its formation to becoming microagglomerations; figure 4(d).

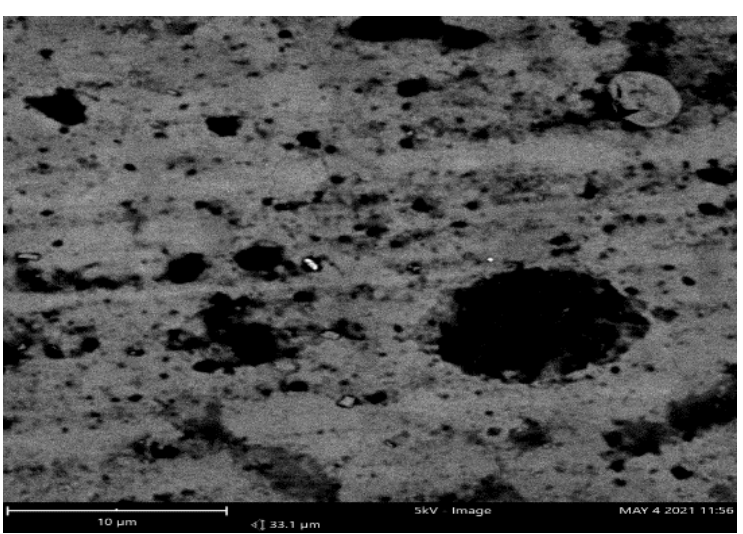

(b)

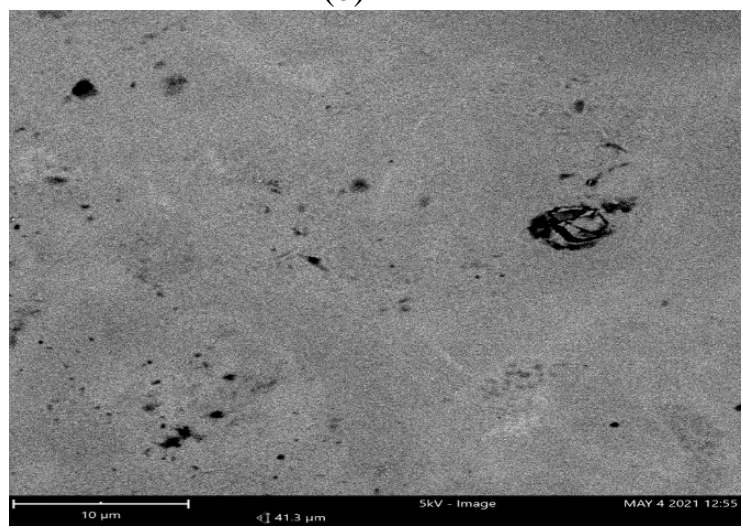

(d)

Figure 4: SEM Images of $\mathrm{Al}$-doped $\mathrm{NiO}$ thin films prepared at $450^{\circ} \mathrm{C}$ with different $\mathrm{Al}$ atomic percentage ratios, (a) samples prepared with 0.5 , (b) with 1.0 , (c) with 1.5 , and (d) with 2 at $\%$. 


\section{Optical Properties of Al-doped NiO Thin Films}

To determine optical properties of the deposited Al-doped $\mathrm{NiO}$ thin films versus $\mathrm{Al}$ doping ratios, transmittance spectra were measured. The obtained results are shown in Figure 5.

We observe from this figure that, transmission decreases with increasing $\mathrm{Al}$ doping ratio in $\mathrm{NiO}$ thin films.

For all Al-doped $\mathrm{NiO}$ films elaborated with different $\mathrm{Al}$ doping ratios, spectra appear two ranges: the first one at wavelengths greater than $400 \mathrm{~nm}$ appearing practically an average transmission between 53 and $76 \%$ and revealing a decrease with increasing $\mathrm{Al}$ doping ratio and, based on calculated film thickness (d), transparence was depending on thickness of samples revealing Beer-Lambert's law as shown in Table 2. The second range is at wavelengths lower than $400 \mathrm{~nm}$ for which transparence decreases speedily for all films exhibiting the beginning of fundamental absorption owing to the transition between the conduction and the valence bands [18].

The calculation of the optical band gap can be playing an essential role to characterize the thin film, which based on optical transmission. It was estimated (calculated) from the classical method by using of the curve at $A=0$ [19], which represented to the drawn of $(\mathrm{A} h v)^{2}$ as a function of ho (see Figure 6) using the following formulas [2-5]:

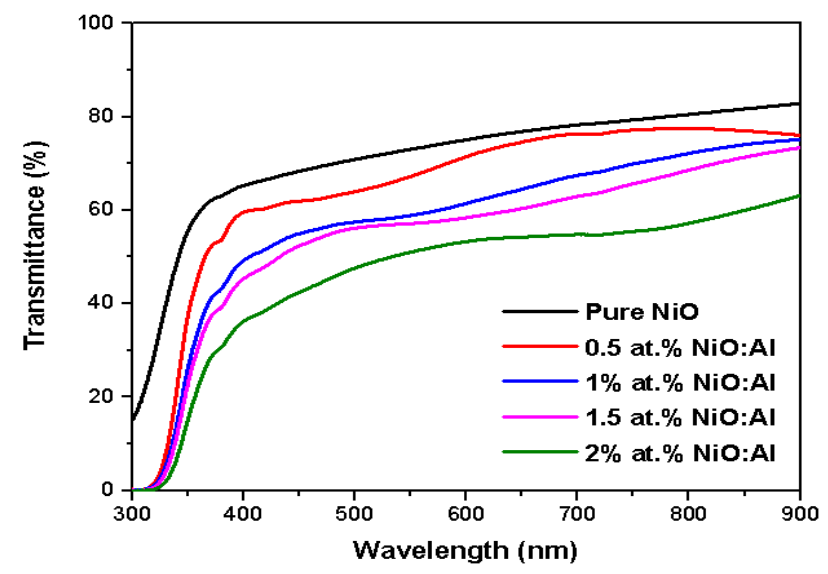

Figure 5: Spectral transmittance curves of $\mathrm{NiO}: \mathrm{Al}$ thin films with various $\mathrm{Al}$ doping ratios.

$$
\begin{gathered}
A=\alpha d=-\ln T \\
(A h v)^{2}=C\left(h v-E_{g}\right)
\end{gathered}
$$

Where $\mathrm{A}$ is the absorbance, $\mathrm{d}$ is the film thickness; $\mathrm{T}$ is the transmission spectra; $\alpha$ is the absorption coefficient values; $\mathrm{C}$ is a constant, ho is the photon energy and $E_{g}$ the band gap energy of thin films.

On the other hand, the disorder in the thin films was characterized by Urbach energy $\left(E_{u}\right)$ which has been calculated by the following equation [20]:

$$
A=A_{0} \exp ^{\left(\frac{h v}{E_{u}}\right)}
$$

Where $\mathrm{A}_{0}$ is a constant and ho is the photon energy.

Figure 7 shows $\mathrm{LnA}$ variation versus photon energy ho for films. Eu values were calculated from reciprocal slopes of the straight lines, as shown in the Figure 7.

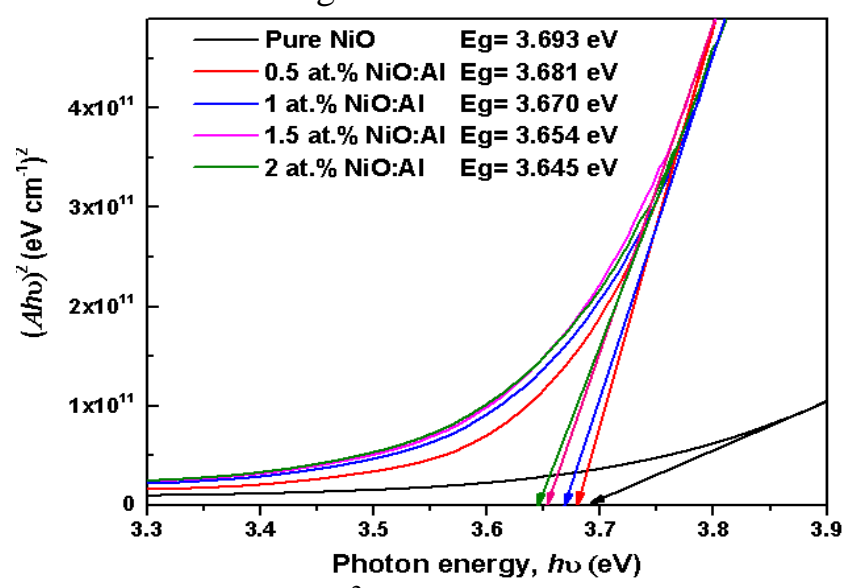

Figure 6: $(\mathrm{Ahv})^{2}$ variation versus hv of each NiO:Al thin film to estimate band gap energy Eg.

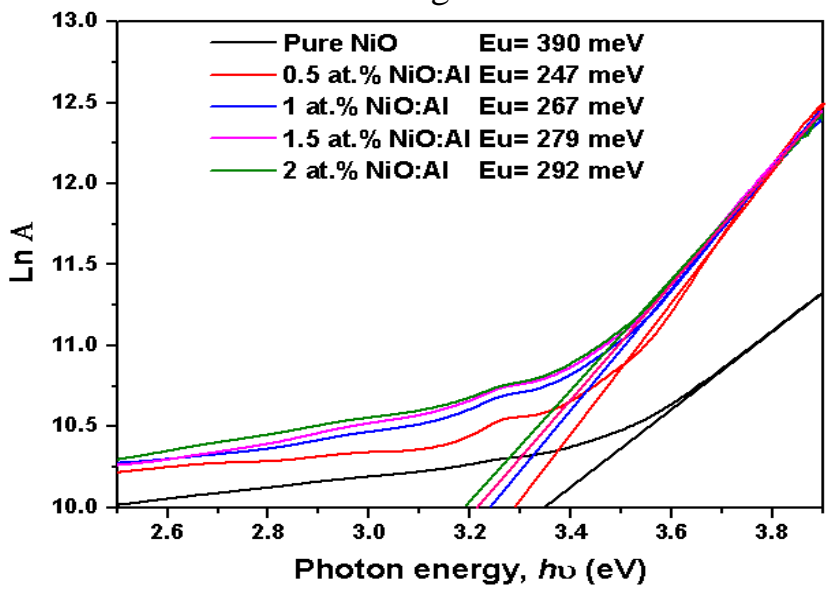

Figure 7: LnA variation versus hv of each $\mathrm{NiO}$ :Al thin film to estimate Eu. 


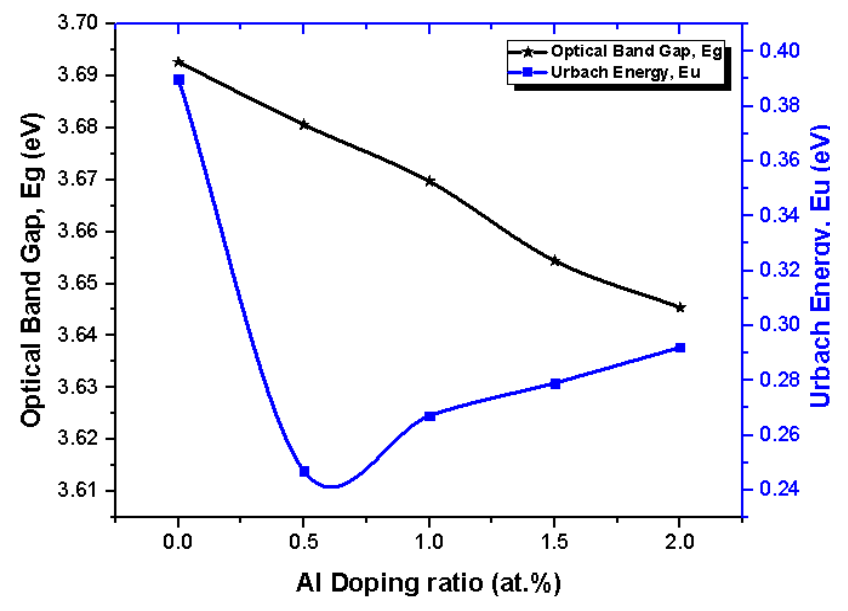

Figure 8: Optical band gap $E_{g}$ vs. Urbach energy $\mathrm{E}_{\mathrm{u}}$ of $\mathrm{NiO}$ : $\mathrm{Al}$ films as a function of $\mathrm{Al}$ doping ratio.
Figure 8 shows the inverse trends of optical band gaps and Urbach energies calculated for doped thin films, the variables are listed in Table 2. As can be seen from this table, the energy band gap is between $3.64-3.70 \mathrm{eV}$ which is in good accord with the Eg values of bulk $\mathrm{NiO}$ (3.6-4 eV) [21] and results carried out in literature [22]. The decrease in the optical band gap with increasing Al doping ratio in $\mathrm{NiO}$ may be attributed to the free carriers' effect as well as to impurity effects on the band gap [23].

The highly decrease of the Urbach energy by $30 \%$ from for Al-doped $\mathrm{NiO}$ films compared to pure $\mathrm{NiO}$ film, can be explained by increasing of crystallite size to $29.2-31.9 \mathrm{~nm}$ and decreasing of the strain.

Table 2: Values of thickness $d$, average transmittance, band gap energy $\mathrm{E}_{\mathrm{g}}$, Urbach energy $\mathrm{E}_{\mathrm{u}}$ and electrical conductivity $\sigma$ of $\mathrm{Al}$-doped $\mathrm{NiO}$ thin films prepared at $450^{\circ} \mathrm{C}$ with various $\mathrm{Al}$ doping ratios.

\begin{tabular}{|c|c|c|c|c|c|}
\hline $\begin{array}{c}\text { Al doping } \\
\text { ratio (at.\%) }\end{array}$ & $\begin{array}{c}\text { Thickness d } \\
(\mathbf{n m})\end{array}$ & $\begin{array}{c}\text { Average } \\
\text { transmittance (\%) }\end{array}$ & $\begin{array}{c}\text { Gap energy } \\
\mathbf{E g}(\mathbf{e V})\end{array}$ & $\begin{array}{c}\text { Urbach } \\
\text { energy Eu } \\
(\mathbf{e V})\end{array}$ & $\begin{array}{c}\text { Electrical } \\
\text { conductivity } \boldsymbol{\sigma} \\
\mathbf{( O h m . c m}^{-\mathbf{1}}\end{array}$ \\
\hline 0 & 154.550 & 71.205 & 3.693 & 0.390 & 0.032 \\
\hline 0.5 & 163.847 & 64.683 & 3.681 & 0.247 & 0.641 \\
\hline 1 & 191.296 & 57.529 & 3.670 & 0.267 & 0.228 \\
\hline 1.5 & 202.103 & 54.550 & 3.654 & 0.279 & 0.234 \\
\hline 2 & 252.289 & 46.416 & 3.645 & 0.292 & 0.098 \\
\hline
\end{tabular}




\section{Electrical Properties of Al-doped NiO Thin Films}

The four-point probes method was used to calculate the electrical conductivity $\sigma$ of Aldoped $\mathrm{NiO}$ films; the measurement was based on the sheet resistance $R_{s h}$. It is obtained by the following expression [24]:

$$
\sigma=\frac{1}{R_{s h} d}=\left(\frac{\pi}{\ln (2)} \frac{V}{I}\right)^{-1}
$$

Where $I$ is the applied current $=0.5 \cdot 10^{-6} \mathrm{~A}$ and $V$ is the measured voltage and $d$ is the film thickness. Figure 9 shows the electrical conductivity and Urbach energy of Al-doped $\mathrm{NiO}$ films plotted as function of different $\mathrm{Al}$ doping ratio. As can see from this plot, the electrical conductivity increased up to maximum value $0.641(\Omega . \mathrm{cm})^{-1}$ obtained with $\mathrm{Al}$ ratio of 0.5 at. $\%$, then decreased by increasing $\mathrm{Al}$ ratio to reach $0.098(\Omega . \mathrm{cm})^{-1}$ at 2 at.\%. As a result of the compositional changes, especially in terms of the formation and occupation of nickel vacancies (defect), these lead to p-type conductivity.

As the ionic radii of $\mathrm{Al}^{+3}$ and $\mathrm{Ni}^{+3}$ ions are very close, by introducing $\mathrm{Al}^{+3}$ ions as the dopant in the $\mathrm{NiO}$ film, it may easily replace the $\mathrm{Ni}^{+3}$ ions or occupy interstitial sites of $\mathrm{NiO}$ matrix [23-25]. However, an addition of an excessive $\mathrm{Al}$ quantity may cause the formation of $\mathrm{Al}_{2} \mathrm{O}_{3}$ and related groups as carrier traps contrary to electron donors, resulting in a decrease in the conductivity and other associated phenomena, that what happened when $\mathrm{Al}$ doping ratio exceed 0.5 at. $\%$.

Figure 8 supports this analysis, the variations of electrical conductivity and Urbach energy are revealing an inverse behavior which means that doping of $\mathrm{NiO}$ by $\mathrm{Al}$ leads to decrease the formation defects of $\mathrm{NiO}$ matrix which appears through the decreasing of Urbach energy and increasing of electrical conductivity in doped films.

It is worth noting that the electrical conductivity $(\sigma)$ of the elaborated Al-NiO films, have p-type character, and the highest electrical conductivity achieved was $0.641(\Omega . \mathrm{cm})^{-1}$ at 0.5 at.\%, with lowest $\mathrm{Eu}$, $0.247 \mathrm{eV}$.

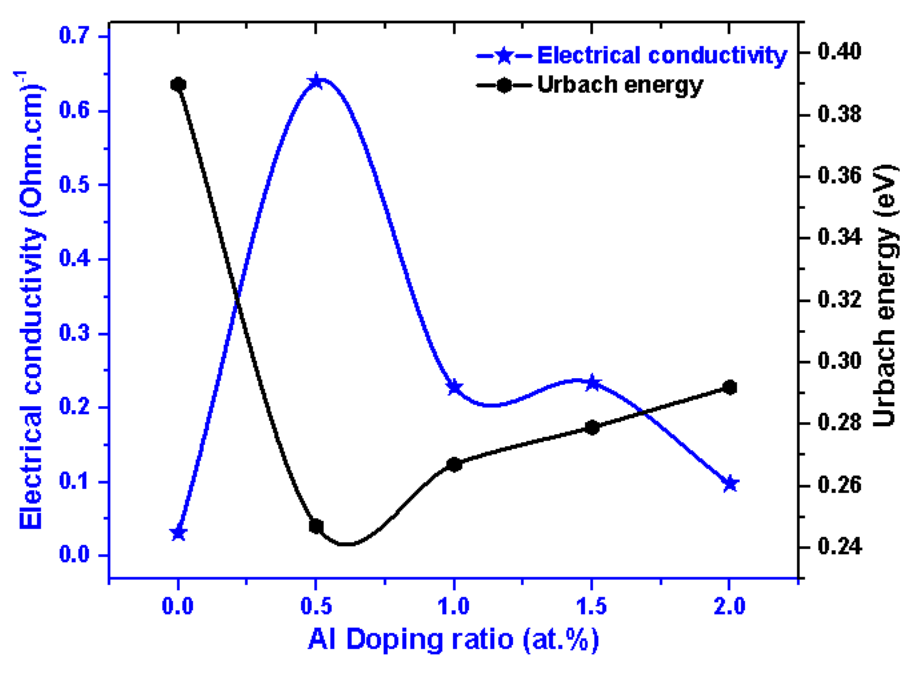

Figure 9: Electrical conductivity $\sigma$ vs. Urbach energy $\mathrm{E}_{\mathrm{u}}$ of $\mathrm{NiO}: \mathrm{Al}$ films with different $\mathrm{Al}$ doping ratio.

\section{CONCLUSION}

In the end, Al-doped $\mathrm{NiO}$ thin films have successfully been elaborated onto glass substrates by solar spray pneumatic method, at around $450^{\circ} \mathrm{C}$ with a different heating way by using a solar furnace. The effect $\mathrm{Al}$ doping ratio $(0,0.5,1,1.5$ and 2 at.\%) on structural, optical and electrical properties was investigated. The followings conclusions summarize the above research work:

(1) XRD patterns of Al-doped $\mathrm{NiO}$ thin films indicate that the obtaining thin films are poly-crystalline with a face centered cubic structure (fcc) and a strong (111) favored orientation for all sprayed films. The structure was improved for doped thin films, the crystallite size increased up to maximum value of $31.9 \mathrm{~nm}$ for sprayed film with 1 at.\% $\mathrm{Al}$ which revealing the nano-structure of the product. SEM images reveal that with increasing $\mathrm{Al}$ atomic percentage ratio, the substrates become better covered and confirm the formation of homogeneous nanostructured films. However, aluminum oxide $\mathrm{Al}_{2} \mathrm{O}_{3}$ was observed when $\mathrm{Al}$ content exceeded 0.5 at. $\%$.

(2) All Al-doped NiO thin films have good transmission in visible region of about $65 \%$. When the $\mathrm{Al}$ doping ratio increased from 0 to 2 
at.\%, a band gap shrinkage of up to $0.048 \mathrm{eV}$ was observed. It is also shown that the doped films by Al have low values of Urbach energy, the minimum value reached was, $0.247 \mathrm{eV}$ at 0.5 at.\% $\mathrm{Al}$ which is the film has less disorder and few defects.

(3) The electrical conductivity of the elaborated Al-doped $\mathrm{NiO}$ thin films increased greatly from $0.03(\Omega . \mathrm{cm})^{-1}$ for undoped $\mathrm{NiO}$ film to $0.1-0.64(\Omega . \mathrm{cm})^{-1}$ for Al-doped $\mathrm{NiO}$ films due to composition changes after aluminum ions incorporation in $\mathrm{NiO}$ matrix. However, an addition of an excessive $\mathrm{Al}$ quantity (exceed 0.5 at.\%) causes the formation of $\mathrm{Al}_{2} \mathrm{O}_{3}$ which resulting a decrease in the conductivity. It can be noted that the conductivity of films have p-type (semiconductor) character.

The good transmittance, widened band gap (3.64-3.70eV) and high electrical conductivity $\left(0.64(\Omega . \mathrm{cm})^{-1}\right)$ obtained for Al-doped $\mathrm{NiO}$ films make them promising candidate for electronic and optoelectronic applications such as photo-detectors (diodes, transistors...) and solar cells.

\section{REFERENCES}

[1] Y.Aoun, R.Meneceur, S.Benramache, B.Maaoui, Sprayed NiO-Doped p-Type Transparent ZnO Thin Films Suitable for Gas-Sensing Devices, Physics of the Solid State 62 (1) 131- 136 (2020).

[2] H.Guezzoun, B.Benhaoua, S.Benramache, Synthesis and characterizations of nanocrystalline

$\mathrm{Na}$ and $\mathrm{Al}$ codoped $\mathrm{NiO}$ thin films, International Journal of Integrated Engineering 12 (1) 204-209 (2020).

[3] Z.W.Shang, H.H.Hsu, Z.W.Zheng, C.H.Cheng, Progress and challenges in $p$ type oxide-based thin film transistors, Nanotechnology Reviews 8, 422-443 (2019).

[4] Mironova-Ulmane N., Kuzmin A., Sildos I., Puust L., Grabis J., Magnon and Phonon Excitations in Nanosized NiO, Latvian Journal of Physics and Technical Sciences 56, 726-737 (2019).

[5] F.J. Garcia-Garcia, P. Salazar, F. Yubero, A.R. González-Elipe, Non-enzymatic glucose electrochemical sensor made of porous $\mathrm{NiO}$ thin films prepared by reactive magnetron sputtering at oblique angles, Electrochimica Acta 20138-44 (2016).

[6] G.S. Gund, C.D. Lokhande, H.S. Park, Controlled synthesis of hierarchical nanoflake structure of $\mathrm{NiO}$ thin film for supercapacitor application, Journal of Alloys and Compounds 741, 549-556 (2018).

[7] I.Manouchehri, D.Mehrparvar, R.Moradian, K.Gholami, T.Osati, Investigation of structural and optical properties of copper doped $\mathrm{NiO}$ thin films deposited by $R F$ magnetron reactive sputtering, Optik 127 8124-8129 (2016).

[8] M. Karyaouia, D. Ben Jemiaa, M. Gannounia, I. Ben Assakera, A. Bardaouia, M. Amloukb, R. Chtouroua, Characterization of Ag-doped $\mathrm{ZnO}$ thin films by spray pyrolysis and its using in enhanced photoelectrochemical performances, Inorganic Chemistry Communications 119, 108114 (2020).

[9] Yahya M. Abdul-Hussein, Huda J. Ali, L. A. Latif, Mudar Ahmed Abdulsattar, Husham M. Fadhel. Preparation of Aldoped $\mathrm{NiO}$ thin films by spray pyrolysis technique for $C O$ gas sensing. $J$ Adv Pharm Edu Res; 9(3):1-6 (2019).

[10] F. A. Garces, N. Budini, J. A. Schmidt, and R. D. Arce, Highly doped $\mathrm{ZnO}$ films deposited by spray-pyrolysis. Design parameters for optoelectronic applications, Thin Solid Films, vol. 605, pp. 149-156, (2016).

[11] J. Wang, P. Yang, X. Wei, and Z. Zhou, Preparation of $\mathrm{NiO}$ two-dimensional grainy films and their high-performance gas sensors for ammonia detection, Nanoscale Research Letters, vol. 10, no. 1, pp. 1-6, (2015).

[12] H.-L. Chen, Y.-M. Lu, and W.-S. Hwang, Effect of film thickness on structural and electrical properties of sputter-deposited nickel oxide films, Materials Transactions, vol. 46, no. 4, pp. 872-879, (2005).

[13] B. Cullity and S. Stock, Principles of $X$ Ray Diffraction, Addison Wesley, Mass, USA, (1978).

[14] A.Diha, S.Benramache, L.Fellah, the Crystalline Structure, Optical and 
Conductivity Properties of Fluorine Doped $\mathrm{ZnO}$ Nanoparticles, Journal of Nano and Electronic Physics 1103002 (2019).

[15] Y.Yulizar, R.Bakri, D.Oky B.Apriandanu, T.Hidayat, $\mathrm{ZnO} / \mathrm{CuO}$ nanocomposite prepared in one-pot green synthesis using seed bark extract of Theobroma cacao, Nano-Structures \& Nano-Objects 16300 305 (2018).

[16] A.G. Habtea, F.G. Honea, F.B. Dejene, The influence of malonic acid on the structural, morphological and optical properties of CdSe thin films prepared by chemical bath deposition method, Inorganic Chemistry Communications 103 107-112 (2019).

[17] N. Khedmi, M. Ben Rabeh, and M. Kanzari, Structural morphological and optical properties of $\mathrm{SnSh}_{2} \mathrm{~S}_{4}$ thin films grown by vacuum evaporation method, Journal of Materials Science and Technology, vol. 30, no. 10, pp. 10061011 (2014).

[18] S. Benramache and B. Benhaoua, Influence of substrate temperature and Cobalt concentration on structural and optical properties of $\mathrm{ZnO}$ thin films prepared by Ultrasonic spray technique, Superlattices and Microstructures, vol. 52, no. 4, pp. 807-815, (2012).

[19] Y.Aoun, M.Marrakchi, S.Benramache, B.Benhaoua, S.Lakel, A.Cheraf, Preparation and Characterizations of Monocrystalline $\mathrm{Na}$ Doped $\mathrm{NiO}$ Thin Films, Materials Research 21 e20170681 (2018).
[20] S. Benramache, Y. Aoun, S. Lakel, H. Mourghade, R. Gacem, B. Benhaoua, Effect of Annealing Temperature on Structural, Optical and Electrical Properties of ZnO Thin Films Prepared by Sol-Gel Method, Journal of Nano- and Electronic Physics 10 No 6, 06032 (2018).

[21] S.A. Mahmoud, S.Alshomer, M.A.Tarawnh, Structural and optical dispersion characterisation of sprayed nickel oxide thin films, Journal of Modern Physics 2 1178-1186 (2011).

[22] B. Maaoui, Y. Aoun, S. Benramache, A. Nid, R. Far, A. Touati, Synthesis and characterization of physical properties of the NiO thin films by various concentrations, advances in materials science, Vol. 20, No. 3 (65), (2020).

[23] S Nandy, U N Maiti, C K Ghosh1 and K $\mathrm{K}$ Chattopadhyay, Enhanced p-type conductivity and band gap narrowing in heavily Al doped $\mathrm{NiO}$ thin films deposited by $R F$ magnetron sputtering, J. Phys.: Condens. Matter 21115804 (2009).

[24] Y.Aoun, Design and development of the solar oven for the preparation of metal oxides-oxides characterization, Doctoral thesis, Mohamed khider University, Algeria (2016).

[25] Rajeh M. Mundle, Hampton S. Terry, Kevin Santiago, Dante Shaw, Messaoud Bahoura, Aswini K. Pradhan, Kiran Dasari, and Ratnakar Palai , Electrical conductivity and photoresistance of atomic layer deposited Al-doped $\mathrm{ZnO}$ films, J. Vac. Sci. Technol. A, Vol. 31, No. 1, (2013). 